\title{
SOME PERTINENT OBSERVATIONS ON THE PATHOLOGY OF TRAUMATIC SPINAL PARALYSIS *
}

\author{
By G. M. BeDbrook, M.S., F.R.C.S., F.R.A.C.S. \\ Royal Perth Hospital, Western Australia
}

INDICATIONS for surgical exploration in patients afflicted by spinal cord injury are always difficult to determine. For years, these indications have been dominated by a natural desire to undertake all that is possible for these severely injured people. Surgery, however, must be undertaken with a firm knowledge of basic pathology, for unfortunately, operative interference does not always confer a benefit but in fact, on careful clinical observation, not only may increase morbidity, but cause death. This is particularly so in those cases of patients with cervical cord injuries, but applies also to those in the lumbo-dorsal spine; e.g.

Mr. S., male, aged 30, admitted to hospital in 1956 with a head injury, peripheral fractures, plus paraplegia due to a lumbo-dorsal dislocation (regarded as being of the unstable type). This fracture dislocation was operatively reduced with an attempt at internal fixation which failed due to fractures of spinous processes. The patient died three days later, not only because of the severity of his injuries but because of his inability to cope with the increased trauma of the operative interference. His death may now have been labelled as supra-renal failure. I am now convinced that without the operative interference, this patient would have survived. His spinal cord and cauda equina were completely severed at the lumbo-dorsal junction by a severe rotational stretching injury resulting in a ragged lesion for which surgery, of course, has no answer.

In an attempt to understand the pathology, and obtain indications for adequate management, surgical or otherwise, all pathological material obtained in the Paraplegic Unit of Royal Perth Hospital over a period of eight years has been very carefully studied and observations made. Of 24 cases for study, one was observed at operation, and 23 at post mortem. The records of pathological specimens of other authors have been collected from an examination of the literature and a study of those cases reported by authors interested in the surgery of the paraplegic.

This paper sets out to record and discuss macroscopic features only. Microscopic examination and its discussion will be attempted at another time.

For too long, in an approach to treatment, surgeons have regarded the main problem of spinal cord damage as being due to compression, whilst I believe that our observations prove that the damage is caused by crushing and stretching as well as rotational shearing stresses resulting in an irrevocable damage to the cord and cauda equina. Operative interference in patients has been designed to remove the compressive factors, but very little, if anything, has been done to overcome the much more difficult problem of the above stresses. Nicoll (1949) states the usual mechanism of injury is hyperflexion, with a forward shearing strain, both being the real problem in the spinal cord injury. There is therefore a varying proportion of destruction and compression.

\footnotetext{
* Part of a paper read in New Zealand at the combined meetings of Australia and New Zealand Orthopaedic Associations.
} 


\section{PATHOLOGICAL OBSERVATIONS}

With neural changes being dominant, only a very brief outline of the observed pathological problems as seen in the bony and ligamentous tissues will be given.

\section{Bony Damage.}

Vertebral Canal. The bony canal is rarely seen to be completely occluded, except in those with severe displacement and where reduction has not occurred by any method. This was not observed in the 23 cases under study. The observed position as seen in the X-ray immediately after admission was always a partially reduced position. This must be accepted as a fundamental observation which affects the understanding and management of these persons.

Osseous Changes. (a) The bony boss or ridge at fracture site. Much has been made of this as a compressive factor needing surgery. During injury the disc causes a bulge of the posterior inferior border of the vertebra above the maximal area of damage (usually of a disc) as shown by the work of Robert Roaf (1960), who observed that the disc was frequently the cause of the fracture. In our specimens, the bony boss consisted of one or all of the following: (see figs. $2 a \& b$ ):

(i) fracture of the postero-superior border of the vertebral body below,

(ii) ossification of the extra-dural haematoma,

(iii) disc debris,

and is also well illustrated in Figure I of three specimens.

These varying pathological lesions are important in:

(i) acting as the fulcrum of stretching,

(ii) causing some compression,

(iii) being associated with peridural scarring (see later with extra dural haematoma).

(b) In only one specimen was much extruded disc material observed in the neural canal, although the disc was damaged in all specimens.

Observations revealed that osseous changes are frequently not confined to two vertebrae but may extend over three vertebrae in many of the more grossly damaged spinal segments. This introduces the surgeon to a fundamental fact concerning the extent of the damage. Extensive damage to bony tissue does not lend itself well to reconstruction and stabilisation by methods using internal fixation, a fact which is well known in other osseous sites.

\section{Neural Damage.}

Longitudinal Damage. In our studied specimens (23 at post mortem and one at operation) there was damage over a certain distance of the cord. This damage was never observed to be localised. Such length of damage explains the seriousness of these cases in the early stages and causes death in cervical cord lesions. It was also observed in those cases dying from late renal failure. The extent of such lesions varies between $\mathrm{I} \mathrm{cm}$. and $5 \mathrm{~cm}$.

Study of Figures $2 a$ and $b$, shows the typical macroscopic features of the acute cases. It is observed that osseous damage extends over three vertebral bodies whilst neural damage is extensive and extends between the two distant markers. 


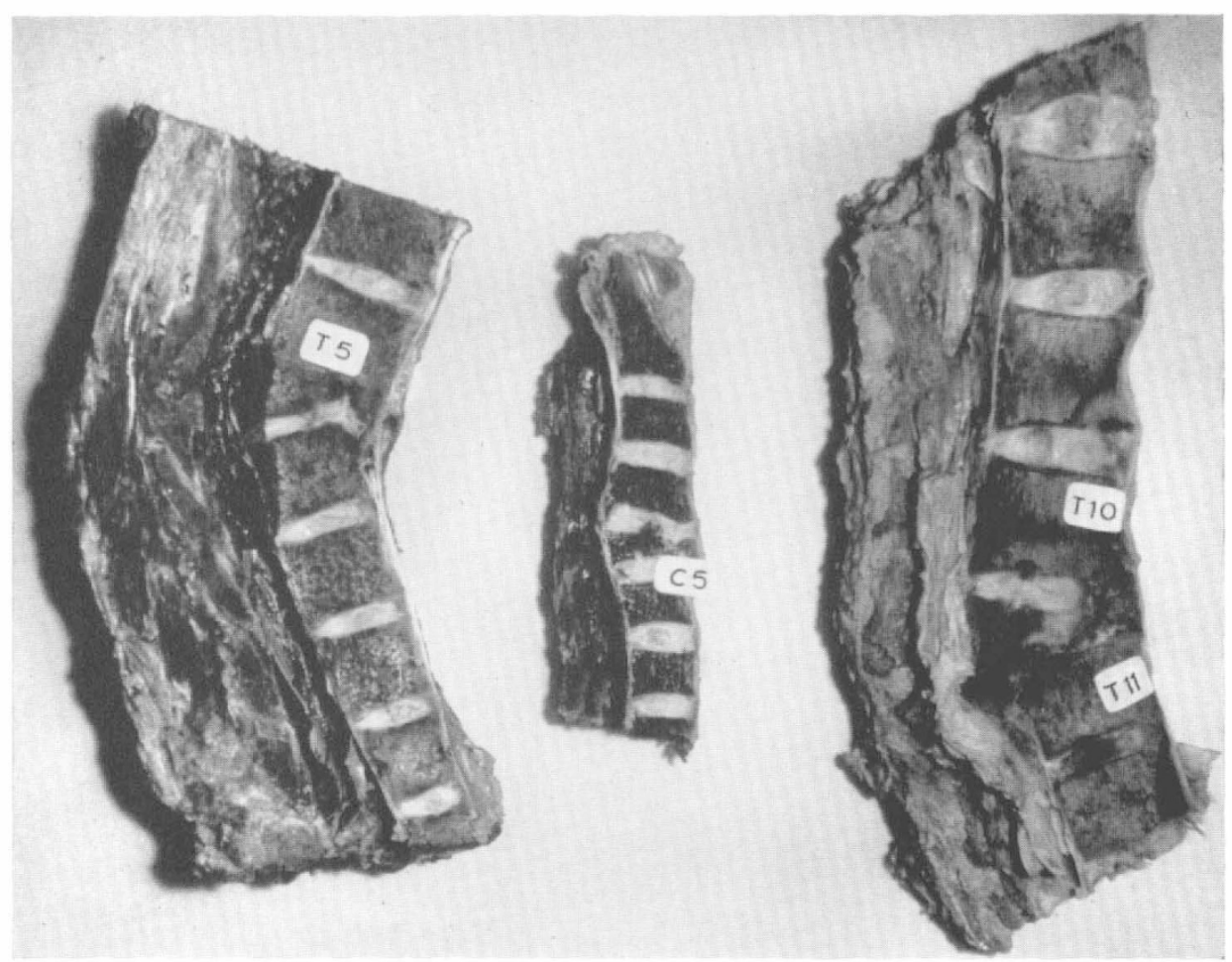

FIG. I

Three specimens to illustrate the bony pathological features (see text).

These features were regularly seen in all acute deaths to a greater or lesser extent and were present in all 23 cases studied at post mortem in all stages.

Cysts (figs. $3 a \& b$ ). These cysts are seen at varying stages of the pathological process. They may be the result of (i) haematomyelia (fig. 4) or (ii) colliquative necrosis.

Such cysts in the cord have been described by Bailey and Badgley (I960) in cases with intermittent trauma. Cyst formation has been recorded by Duncan (see Windle, I955), when the cords of rats were inadvertently damaged during experimental cord operation.

The ultimate pathological manifestation of trauma takes time to occur, so that a cord may look quite normal when exploration is undertaken within the first 24 hours, and yet later at post mortem, gross changes are observed. This has been noted by many surgeons, e.g. Schneider (I95I, 1955), who quotes such a case. Pathological changes are continuing processes, ultimately conditioned by the onset of gliosis and fibrosis against which the surgeon has no power. Indeed, a surgical exploration may increase this problem rather than diminish it, even though such is an extradural operation.

Colliquative necrosis is a liquifying type of tissue death seen not uncommonly in the central nervous system. It may be caused by various agencies acting singly 

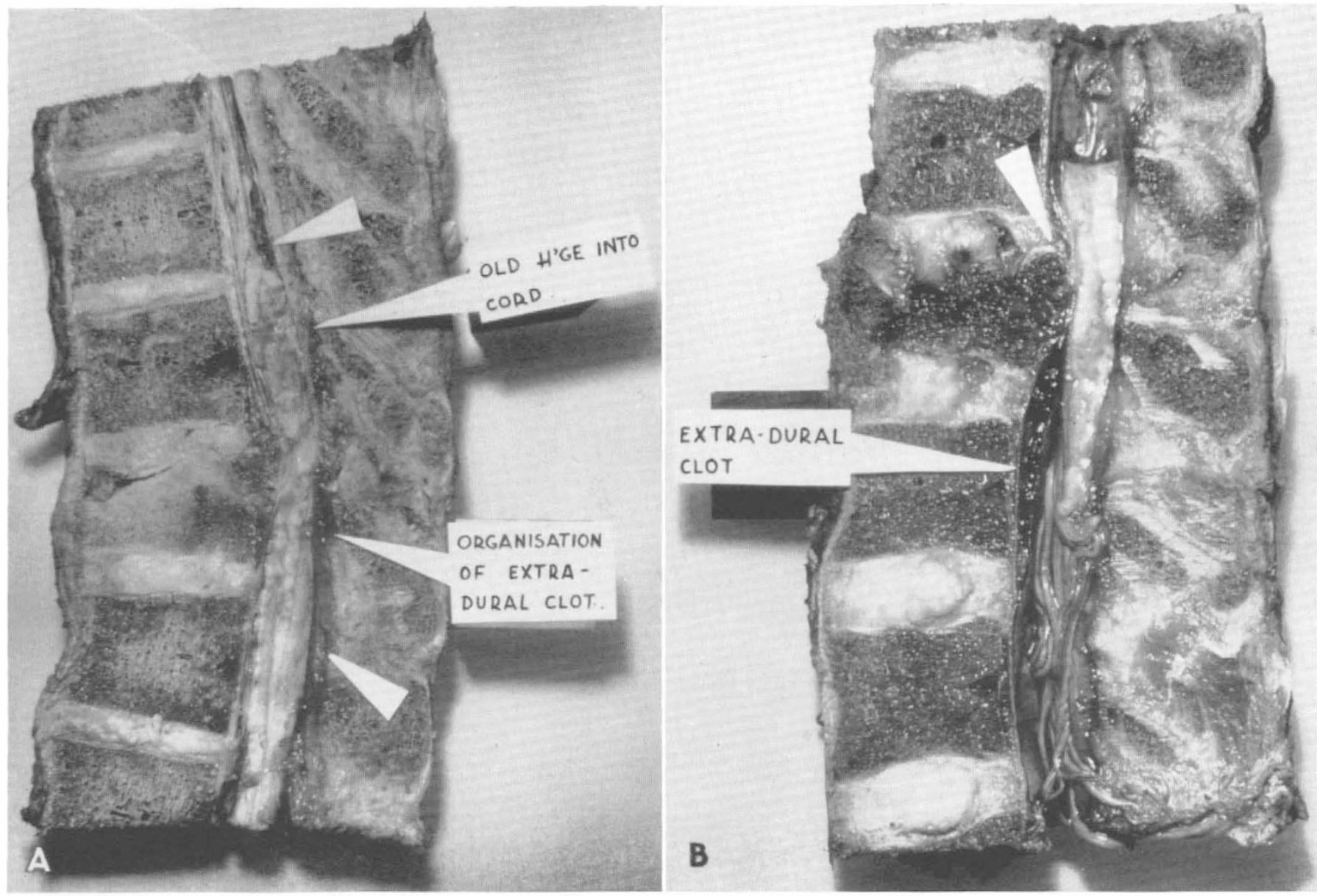

(a) Shows the early macroscopic pathological features, both osseous and neural. (b) Shows the early macroscopic pathological features, both osseous and neural. 


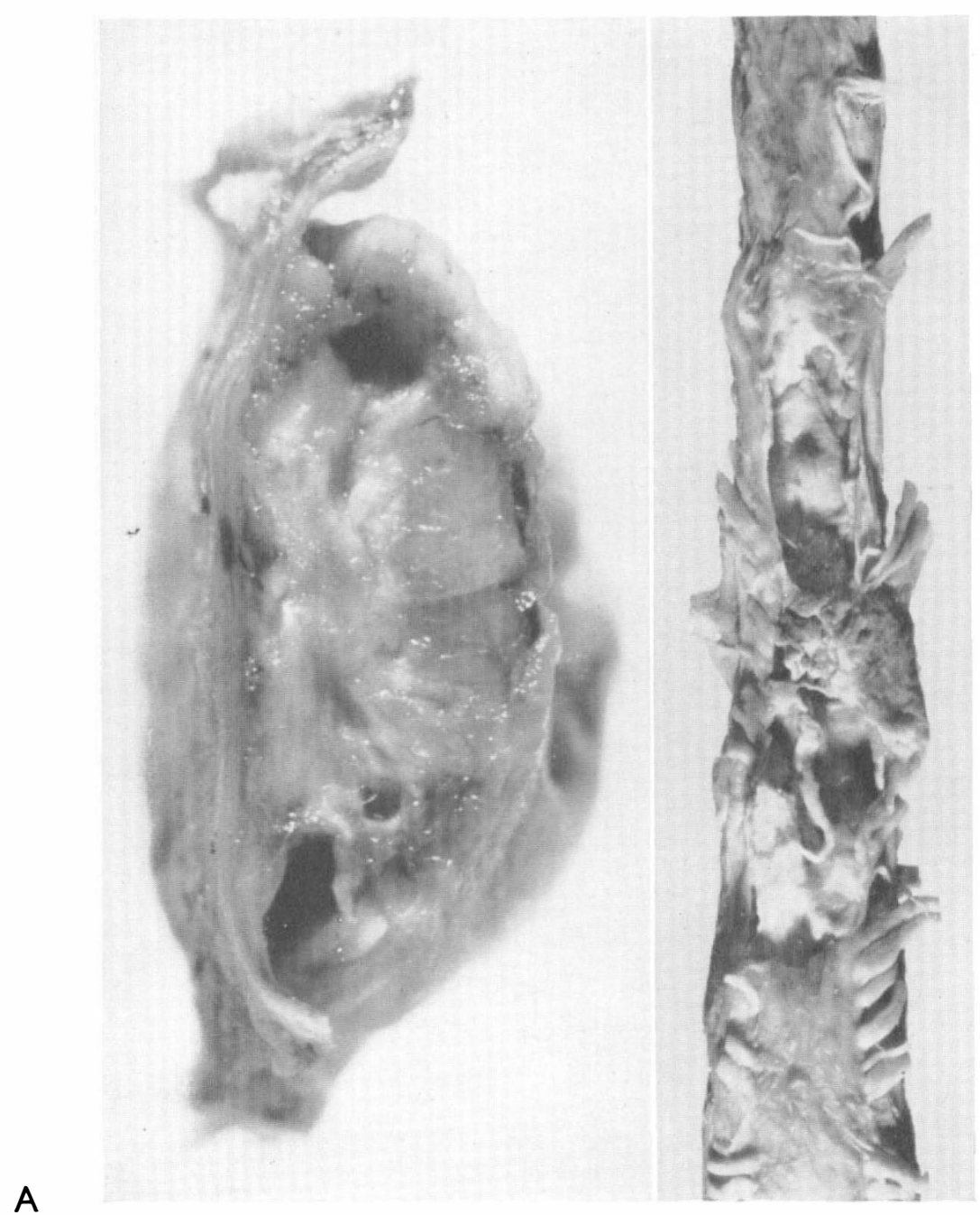

B

FIG. 3

(a) Shows cysts in the spinal cord (cervical) with intact posterior columns. (b) Shows extensive cavitation in the spinal cord.

or together, such as direct trauma, oedema, ischaemia, infection. This is undoubtedly the most common pathological problem in spinal cord trauma. Surgeons have tried to prevent it by decompression, but their very interference may increase the factors causing its occurrence, as can be appreciated from our consideration of its casual factors. Microscopic changes have been observed in our specimens in cases observed at post mortem within 24 hours of accident on cords reported macroscopically as normal.

Injury caused by hyperextension. Two specimens have been examined in which the patient had had a hyperextension injury of the cervical column prior to 


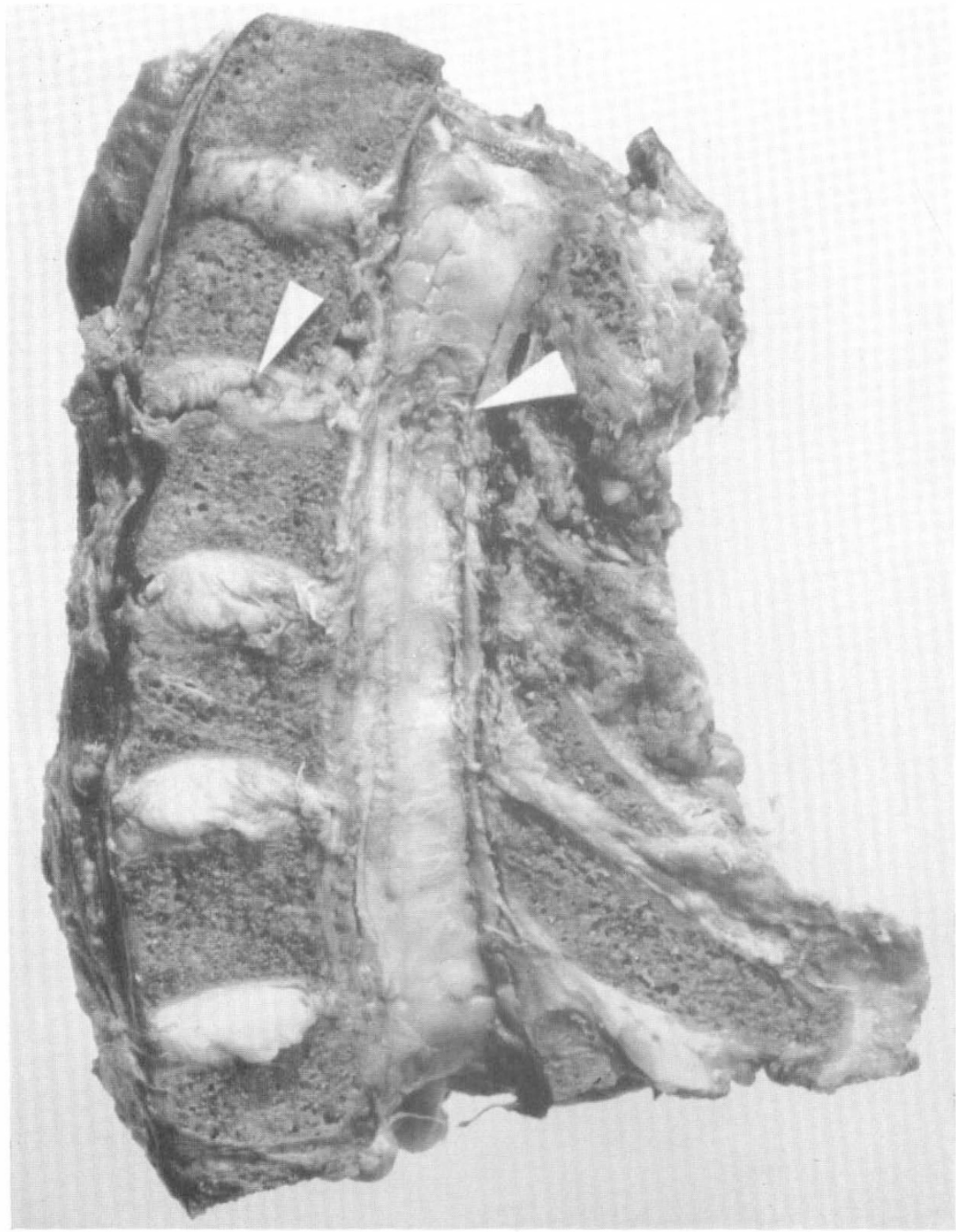

FIG. 4

Early case of haematomyelia.

death. In both specimens the observed features were similar to those recorded above. Cord damage over one to two centimetres was caused by the stretching of the cord over the wedge formed by the laminae of the vertebrae above and the vertebra below, plus the 'edge' of the ligamentum flavum. Another patient has been encountered in whom the anterior portion of the cord survived the hyperextension injury. He had a posterior cord lesion resulting in loss of all forms of posterior column sensibility and also loss of some of the lateral column function, whilst the anterior columns and the pyramidal tracts survived. This patient eventually died. Unfortunately, post mortem was refused.

Root Damage. The problem of root damage was observed in one specimen 
where as well as actual rupture of nerve fibres over quite a length of the rootlets, there was also evidence of stretching and a bunched up appearance and thinning of the roots. In another case, the nerve roots had been torn across in very much the same way as a piece of string would tear following a very ragged type of violence. Such observations explain the clinical symptoms of patients with lumbo-dorsal spine injuries.

Such appearances of the nerve roots explain the very mixed clinical signs of the patient. Only those rootlets with intact sheaths are capable of recovery. It has not been substantiated that early fixation can assist to preserve rootlets which ntherwise may be further damaged. It can be seen from Figure 5 that gross

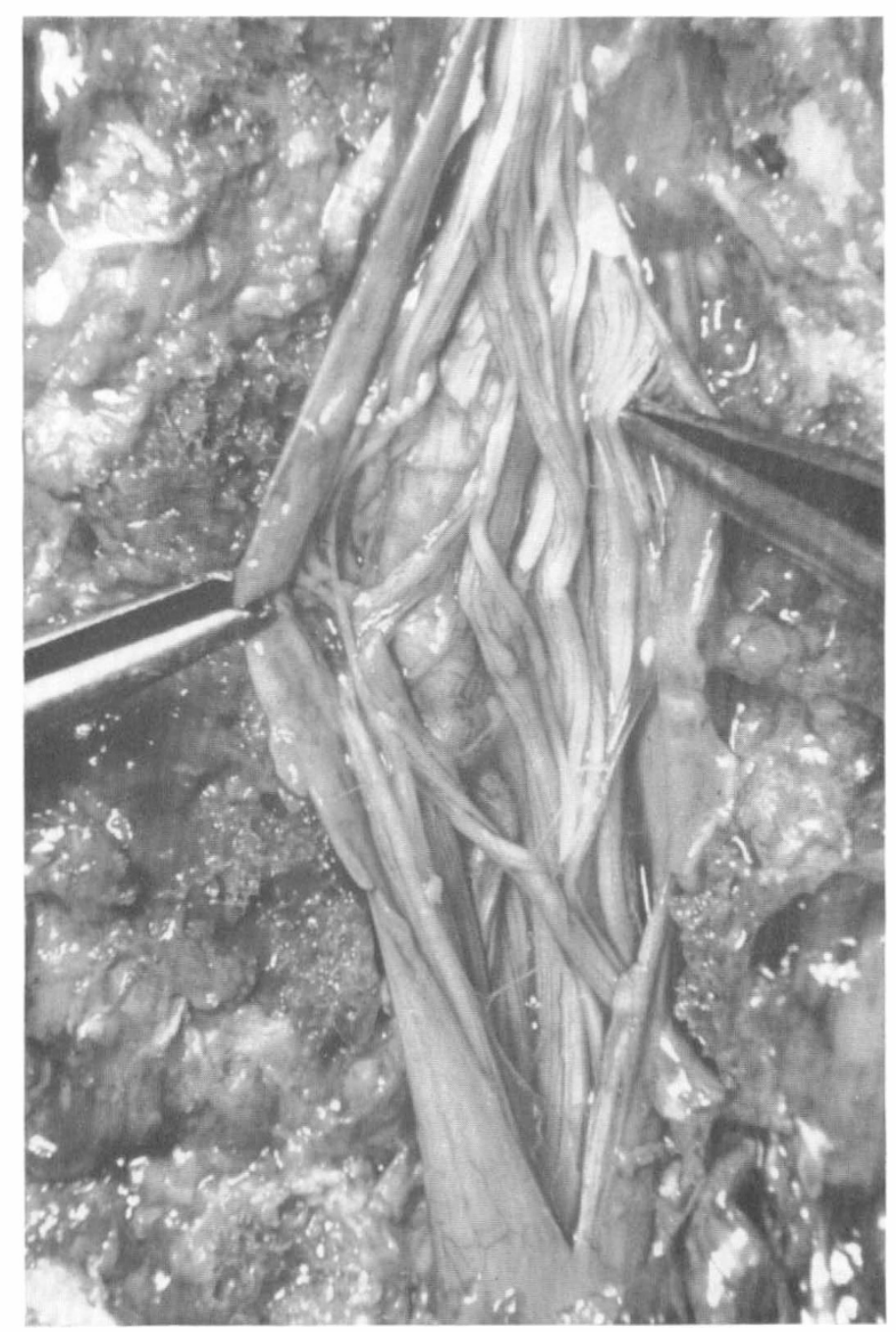

FIG. 5

Shows extensive root damage but no continuing compression. 
stretching and angulation caused the damage, but no continuing compression is present. Further damage could only occur with repeated exaggerated flexion and such can be prevented by a conservative approach to the problem of reduction and maintenance.

A clinical case illustrates and amplifies this observation well.

K. C., age I9, admitted I957, head injury with concussion, gross cerebral irritability and an unstable fracture dislocation TI2-LI, with cauda equina sparing (in sensation only) of L2 and L3. Any surgery was contra-indicated by his head injury. Despite his violent movements, mainly flexion in attempting to sit up, not fully combatted by sedation, he failed to deteriorate. Motor power returned in $\mathrm{L}_{2}$ and $\mathrm{L}_{3}$ within three months, his fracture dislocation healing in an unreduced position.

Arachnoiditis. This is the ultimate result of severe trauma, and was seen in all late cases. It is the observed cause of late paraparesis which may develop years after traumatic lesion of the cord.

Oedema and Thrombosis. Oedema can rarely be demonstrated at post mortem, but accounts for transitory worsening of paralysis. Oedema is frequently the cause of cerebrospinal fluid block which may be transitory. Thrombosis also occurs and is one cause of late destruction, no gross evidence of this could be found in our specimens. (fig. 6).

Gross Fibrosis with constriction of the thecal sheath is the ultimate enemy

This problem can be made worse by operation. Fibrosis has been produced experimentally by Windle and associates (1955), varying directly with the type of trauma; thus as expected, the clean concise wound heals with the least glial changes. Ragged wounds are those one can only heal by such.

\section{DisCUSSION}

Examination of literature reveals many observations on pathology. Pathetically, it also reveals that universal failing of us all to make accurate observations, e.g. Freeman and Russell record a case of a male aet. I5, quadriparetic, made quadriplegic by manipulation and two laminectomies, the first of which had no record made, the second showed gross cord damage with bony spicules in the pulped cord. Freeman (I955) goes on to record five other cases all of whom showed dense arachnoiditis, extruded discs and central cavities. Clinically, all these cases were incomplete. He describes a syndrome of temporary ptosis, miosis, anhidrosis, seen in cervical cases which indicate a central cyst formation which, it is stated, can be prevented by early laminectomy and decompression. No real proof for this can be found. Such a small series can hardly be conclusive, particularly when experimentally cysts can be caused by a variety of types of traumatic onslaught (see Windle and associates, I955).

Richard C. Schneider et al (1954) records some of his pathological observations in a syndrome of anterior cervical cord injuries needing urgent laminectomy. With his syndrome the present author agrees, but not with his indications for operation. Pathologically his cases did not show an isolated prolapsed disc or compression amenable to surgical incision. This author mentions destruction, but does nor give emphasis to mechanisms of stretching in his 13 cases in which only one was doubtfully helped by operation, although his records are difficult to follow because 


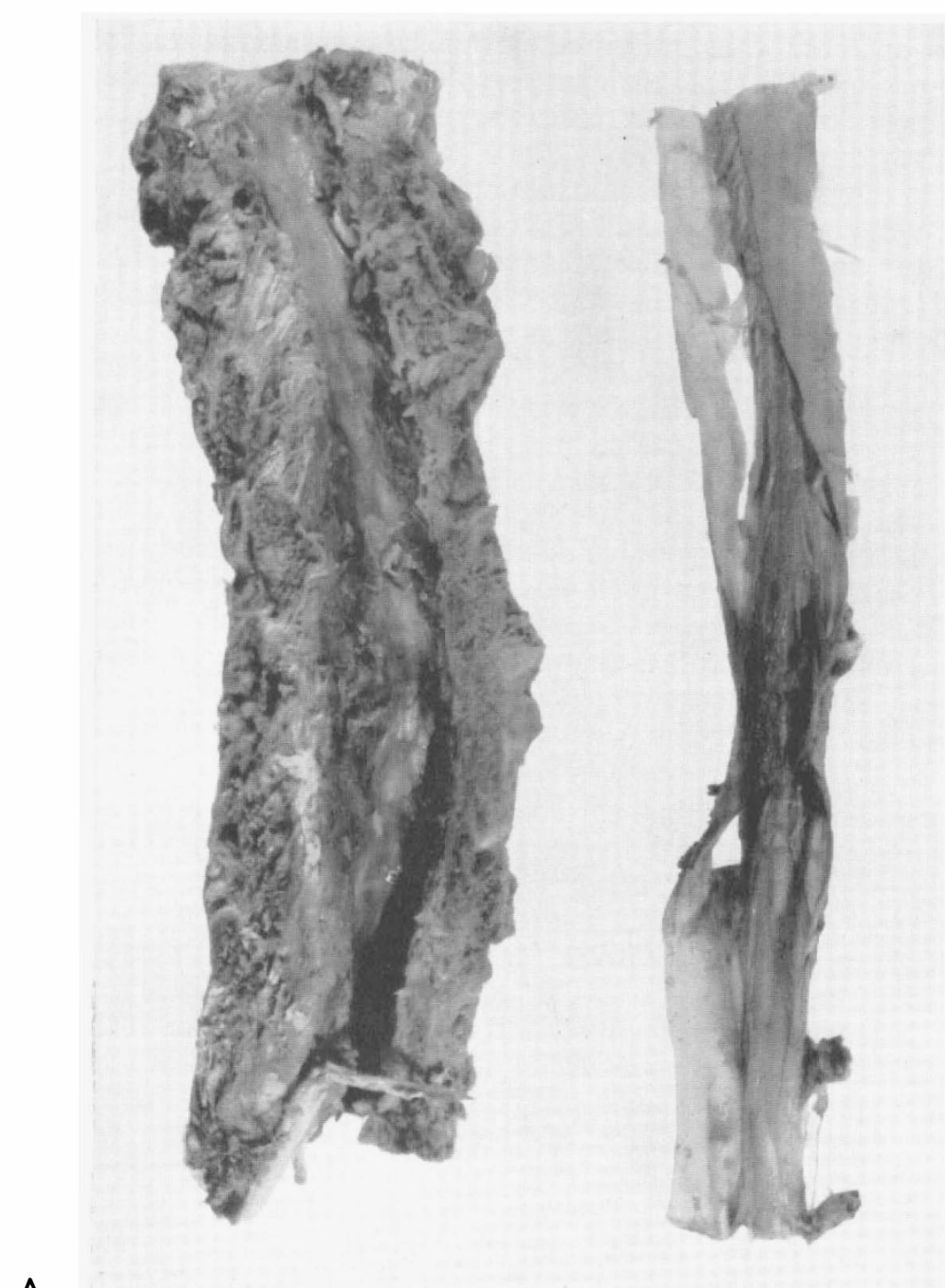

A

FIG. 6

(a) The osseous specimen. Note the absence of any canal occlusion. (b) The gross fibrosis over a length of the cord.

of lack of complete information. This was the case of a white male, aged 33, a paraplegic subsequent to a fracture dislocation of $\mathrm{T}_{3}$ on $\mathrm{T}_{4}$ and $\mathrm{T}_{\mathrm{O} O}$ on $\mathrm{T}_{\mathrm{II}}$. Pre-operatively posterior column sensation was intact over the whole of the body. Two operations were undertaken, one at $\mathrm{T}_{3}$ and $\mathrm{T}_{4}$, where a 'posterior ridge' was chiselled away; this being done on the fourth post-accident day and the second operation on the ninth post-operative day, when $\mathrm{T}_{9}$ and $\mathrm{T}_{\text {I I laminectomy was }}$ performed, the cord being found to be 'normal'. By six weeks after the operation, both right and left lower limb had muscular power. The author stated that 
surgery had aided the patient as the original operation exposed a tightly compressed cord and that operation thus prevented chronic compression of the cord. In view of the fact that the patient had an incomplete lesion from the beginning, the present author is doubtful whether such surgery was advisable, particularly as no spinal block was demonstrated.

Operation can only assist when pathological factors exist that can be remedied by such, e.g. removal of a disc and relief of compression by a neural arch fracture. Such are rarities occurring as isolated causes of quadriplegia.

The present author believes surgery in such cases to be unnecessary for the following reasons:

I. Total pathological examination in those cases coming to post mortem reveals changes as already discussed and that these are not remediable by surgery.

2. Clinically such cases frequently show recovery without operation, a fact observed by many.

3. The so-called anterior bulge does not cause compression. In the present author's clinical series not one of such cases ever had permanent spinal block.

4. It has not been proved that such surgery enhances and increases the recovery rate, in fact, writers such as Bors (1956), Beatson (1963), Munro (I96I), have produced evidence to the contrary.

In I 3 cases of anterior spinal cord contusion reported by Schneider (I95I) the following changes were reported: Extra dural haemorrhage 2; Disc damage 9; Laminal fracture 2; Cyst or necrosis 3; Arachnoiditis 5; Oedema I; C.S.F. Block 0; Partial or no block Io; Fracture 'tear-drop' 7.

Most of these observations were made at operation, and very little can be concluded from the tabulation. This author concluded: 'it is impossible to differentiate destruction from compression and therefore operation indicated'. I agree with the difficulty, but I venture to observe that his observed facts and ours show how infrequently block and compression are present. In his series, no record of block exists. In all recorded cases the frequency of destruction is obvious. I believe further onslaught surgically may tip the balance for the worseand in fact has in at least five cases-two of mine and three of this author's.

A series of cases have been reported by Bailey (I960) where laminectomy was delayed because of spontaneous recovery, the paralysis being due to oedema. This was also observed in two cases operated on by the same author.

Stress-strain phenomena in the spinal cord have not been reported, but Bradley and Sunderland (I96I) have shown that spinal nerve roots are more vulnerable than nerve trunks to mechanical stress. This is related to the absence of perineurium in the nerve root as against the nerve trunk. It is possible therefore that the spinal cord, because of its structure, is itself much more vulnerable to stress than its nerve rootlets and the peripheral nerve, in that order. This, it is hoped, will be checked experimentally in the next few years and was commented on by Holdsworth (I954).

Experimentally, there have been many workers in this field. Their general contribution has been towards elucidation of the natural pathological changes in animal experiments. Thus Tarlov's (1953) experiment on dogs would indicate that distortion rather than ischaemia is the dominant aetiological cause of acute 
paralysis in compression injury. This is confirmatory evidence of the observed changes in the adult human.

Duncan (1955) reporting on experimental compression of the spinal cord in the monograph edited by Windle, found that cavitation resulted when the experimental ligature in the cord caused initial damage, but not if such was carefully avoided.

Much work has also been reported (Windle, 1955) on the factors involved in the possibility of regeneration in the spinal cord. Trauma of the type usually seen in cases of traumatic paraplegia does not allow the best conditions for survival or regeneration. The full documentation of the Stewart-Hart case from the Pennsylvania Hospital, and recorded by Lockhart in Windle's review, shows clearly how experimental work is helping to clarify the problems of spinal cord pathology after trauma.

By producing traumatic lesions of the cord under certain conditions the results show changes encountered in the ragged lesions comparable to those changes described in the above specimens. The pathology changes in spinal cord injuries has not hitherto been fully described and need careful consideration. We have followed 27 cases of quadriparesis and i9 cases of quadriplegia. Of the incomplete cases, not one deteriorated in hospital permanently, but two cases did deteriorate temporarily because of oedema. Of the cases with 'complete' quadriplegia, four showed useful recovery, so that a previous statement as seen in my original communication (Bedbrook, I959) needs modification.

J. McC., male, age 35, compression injury of cervical column at $\mathrm{C}_{7}$ subluxation C6 on $\mathrm{C}_{7}$. Admitted I2 hours after accident by diving. Complete quadriplegia on admission. Showed recovery in left lower limb by 24 hours; this then disappeared, thought to be due to compression. Advised surgery; theca appeared normal. Neurological recovery commenced at six weeks. Patient left hospital able to walk well with crutches. Comment: Surgery not needed; block not demonstrated.

R. M., male, age I6, flexion dislocation $\mathrm{C}_{4}-5$, complete quadriplegia. Admitted six hours after accident; fracture dislocation reduced easily with Crutchfield forceps. Neurological recovery occurred five days later and recovery was excellent.

N. R., male, age 24, compression fracture dislocation $\mathrm{C}_{5}$ on $\mathrm{C} 6$ admitted 12 hours after accident; complete for three days, then showed quite good recovery. Can walk well without crutches.

E. B., male, age 25, compression injury C5-6; complete for six days, then good recovery so that now walks well with crutches.

Before trying to assess the merits and demerits of surgical interference, the surgeon must have all the facts in front of him in regard to pathology; bony, ligamentous and neural. Accurate observation is needed, and then careful thought, using the observed facts of the whole injury (bony, ligamentous and neural), will, I am sure, deter even the most ambitious from undertaking surgical procedures very often.

In a previous communication (Bedbrook, 1959) four patients in our then series (at that stage some Io per cent.) were encountered where a thorough review made me decide that operation indeed caused deterioration-fortunately, in three this was only of a temporary nature. A review of patients treated with and without 
laminectomy by Bors in 1956 showed that the overall improvement was greatest in those both quadriplegic and paraplegic, where no operative interference was deemed to be necessary.

With all these observations as above discussed, reasons for operative interference are few. The following may be caused by such procedures:

I. Further cord damage (proven experimentally and clinically);

2. Extradural haemorrhage with ossification later;

3. Interference with blood supply, and thus an already insulated cord can be made worse - particularly incomplete cases;

4. Bony collapse is not preventable by operation and fixation by wire or plates;

5. Death post-operatively by respiratory failure.

The present author is quite certain of the inadvisability of operation in incomplete lesions, particularly when lumbar puncture fails to reveal a subarachnoid block. This cannot always be accurately assessed within a few hours of accident. Operative interference has rarely been proved to be of assistance, and not uncommonly can be the final stress causing complete cord damage when a cord has not been completely severed originally.

\section{SUMMARY}

In an attempt to elucidate the pathological problem in spinal cord injury associated with fracture dislocations of the lumbo-dorsal and cervico-dorsal column, observations have been made on post mortem specimens at the Paraplegic Unit of the Royal Perth Hospital. These include 23 specimens in all stages of post accident state from one day to 20 years, observations being made on the bony, ligamentous, disc and neural lesions. Important in those observations are those in the neural tissue where it has been observed that the lesion is always one over some distance. Frequently there are cysts present, the cord is crushed in certain injuries, and there is frequently root damage of a number of types where an arachnoiditis and peridural scar are observed. This epidural scar has already been proved to be made worse by operative interference. Oedema and changes in the C.S.F. are commented upon.

With these pathological problems in mind, comment is made on the natural history of the disease, and the use and disuse of operative interference in the early stages.

The author believes that these observations prove quite conclusively that in very few cases (and mainly for bony reasons) will operative interference be justified.

A series of pathological observations obtained from the literature are briefly commented upon.

Acknowledgment. The Author wishes to acknowledge the assistance given by Mr. R. B. Van Raalte (Department of Medical Illustrations), Royal Perth Hospital and Mrs. M. Jackson for secretarial assistance.

\section{RESUMÉ}

Des observations anatomo-pathologiques en vue d'élucider les problèmes que posent les atteintes de la möelle epinière associées à des fractures dislocations du rachis dorsolombaire ou cervico-dorsal ont été éffectués à l'Hopital Royal de Perth, sur des spécimens receuillis à l'autopsie. 
Cette étude comprend 23 specimens, à tous les stages après l'accident, depuis le premier jour jusquà vingt ans après; les observations portent sur les lèsions de l'os, des ligaments, des disqies et la substance nerveuse.

L'atteinte du tissu nerveux est très important et se manifeste toujours sur une grande longueur. La présence de cystes est fréquente, la substance nerveuse est dans certaines atteintes, écrasée reduite à une pulpe, et il y a fréquement une atteinte des racines avec association d'arachnoidite et des cicatrices épidurales sont aussi observées. Il a déjà été prouvé que cette atteinte épidurale a été aggravée par les interventions chirurgicales. La présence d'oèdéme et les changements dans le liquide céphalo-rachidien ont été mentionées dans le texte. À la lumière de ces travaux anatomo-pathologiques la discussion porte sur l'évolution naturelle des lésions et l'emploi ou non de procédures operatoires dans les cas recents. L'auteur pense que ces observations prouvent, d'une facon concluante que l'acte operatoire n'est justifié que dans très peu de cas, et, seulement en ce qui concerne des raisons d'ordre osseux.

Des commentaires ont été portés sur une séries d'observations obtenus de la littérature.

\section{ZUSAMMENFASSUNG}

Ein Versuch wird gemacht, das pathologische Problem der traumatischen Querschnittsläsionen nach Dislokationsfrakturen der lumbo-dorsalen und cervico-dorsalen Wirbelsäule an Hand von im Spinalen Centrum des Royal Perth Hospital erhobenen post mortem Befunden zu klären. Die Beobachtungen sind an 23 Präparaten der verschiedenen Stadien nach dem Unfall vom ersten Tag bis zu 20 Jahren, gemacht worden und betreffen Läsionen des Knochens, der Bänder, Zwischenwirbelscheiben und der nervösen Elemente. Von besonderer Wichtigkeit sind die Läsionen der nervösen Gewebe, die sich immer über eine gewisse Länge erstrecken. Häufig sind Cysten vorhanden, in manchen Fällen ist das Rückenmark zerquetscht und häufig bestehen Wurzelschädigungen verschiedener Art, wo Arachnoiditis und peridurale Narben gefunden wurden. Es wurde beobachtet, dass die peridurale Narbenbildung durch operative Intervention verstärkt wird.

Ödem und Liquorveränderungen werden ebenfalls besprochen.

Im Lichte dieser pathologischen Erscheinungen wird die Frage der Anwendung und Missbrauchs operativer Intervention besprochen.

Der Autor ist überzeugt, dass die erhobenen Befunde einen eindeutigen Beweis dafür darstellen, dass operative Massnahmen nur in sehr wenigen Fällen (hauptsächlich wegen der Knochenläsionen) gerechtfertigt sind.

Es werden auch eine Anzahl pathologischer Beobachtungen aus der Literatur besprochen.

\section{REFERENCES}

Bailey, R. W., \& BAdGley, C. E. (I960). F. Bone ft. Surg., 42a, 565.

BEATSON, T. R. (1963). F. Bone ft. Surg., 45b, 2 I.

BEDBROOK, G. M. (1959). Aust. N.Z. F. Surg., 28, 245.

Bors, E. (1956). Bull. Los Angeles Neurol. Soc., 21, I05.

DunCan, D. (I955). Regeneration in the Central Nervous System, ed. Windle, p. 247.

FreEMAN, L. W., \& Russell, J. R. (1955). F. Neurosurg., 12, 584.

HoldswORTH, F. W. (1954). Ann. R. Coll. Surg. Engl., I5, $28 \mathrm{I}$.

Munro, D. (1961). Nerw Eng. F. Med., 264, 573.

Nicoll, E. A. (I949). F. Bone ft. Surg., 3ib, 376.

RoAf, R. (1960). F. Bone ft. Surg., 42b, 810.

SCHNEIDER, R. C. (I95I). F. Neurosurg., 8, 360.

SCHNEIDER, R. C. (I955). F. Neurosurg., 12, 95.

SChNeIder, R. C., Cherry, G., PANTEK, H. (I954). F. Neurosurg., II, 546.

Schneider, R. C., \& KaHN, E. A. (I956). F. Bone ft. Surg., 38a, 985.

Schneider, R. C., \& Kahn, E. A. (I959). F. Bone Ft. Surg., 4ra, 457.

Sunderland, S., \& BRAdley, K. C. (I96I). Brain., 84, I20.

Tarlov, I. M., \& Klinger, H. (I954). Arch. Neurol. Psychiat., 71, 27 I.

Vitale, S. (1953). Arch. Neurol. Psychiat., 70, 813.

WindLe, W. F. (1955). Regeneration in the Central Nervous System, p. 24I. ed. Windle. 